A History of Modern Indonesia since c. 1300 


\title{
A History of Modern Indonesia since C. 1300
}

\author{
M. C. RICKLEFS
}

Director of the Research School

of Pacific Studies at the

Australian National University

Second Edition

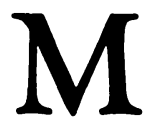

MACMILLAN 
(c) M. C. Ricklefs 1991, 1993

All rights reserved. No reproduction, copy or transmission of this publication may be made without written permission.

No paragraph of this publication may be reproduced, copied or transmitted save with written permission or in accordance with the provisions of the Copyright, Designs and Patents Act 1988, or under the terms of any licence permitting limited copying issued by the Copyright Licensing Agency, 90 Tottenham Court Road, London W1P 9HE.

Any person who does any unauthorised act in relation to this publication may be liable to criminal prosecution and civil claims for damages.

First published 1991 by THE MACMILLAN PRESS LTD

Houndmills, Basingstoke, Hampshire RG21 2XS and London

Companies and representatives throughout the world

ISBN 978-0-333-57690-8

ISBN 978-1-349-22700-6 (eBook)

DOI 10.1007/978-1-349-22700-6

A catalogue record for this book is available from the British Library.

First edition reprinted seven times

Second edition 1993

Reprinted 1994 (twice) 
For Norman, Charles and Deborah 


\section{Contents}

List of Maps $\quad$ ix

Preface to the First Edition $\quad$ x

Preface to the Second Edition xii

A Note on Orthography xiii

Abbreviations $\quad$ xiv

I The Emergence of the Modern Era

1 The Coming of Islam 3

2 General Aspects of Pre-Colonial States and Major Empires, $\begin{array}{ll}\text { c. } 1300-1500 & 15\end{array}$

3 The Arrival of the Europeans in Indonesia, c. 1509-1620 22

4 The Rise of New States, c. 1500-1650 32

$5 \quad$ Literary, Religious and Cultural Legacies $\quad 50$

II Struggles for Hegemony, c. 1630-1800

6 Eastern Indonesia, c. 1630-1800 61

7 Java, c. 1640-82 69

8 Java, Madura and the VOC, $c .1680-1745 \quad 81$

9 Java and the VOC, $c$. 1745-92 94

III The Creation of a Colonial State, c. 1800-1910

$\begin{array}{ll}10 \text { Java, 1792-1830 } & 109\end{array}$

11 Java, 1830-1900 119

12 The Outer Islands, c. 1800-1910 131 
viii A HISTORY OF MODERN INDONESIA

IV The Emergence of the Idea of Indonesia, c. 1900-42

13 A New Colonial Age 151

14 The First Steps towards National Revival, c. 1900-27 163

15 Repression and Economic Crisis, 1927-42 181

V The Destruction of the Colonial State, 1942-50

16 World War II and the Japanese Occupation, 1942-5 199

17 The Revolution, 1945-50 212

VI Independent Indonesia

18 The Democratic Experiment, 1950-7 237

19 Guided Democracy, 1957-65 257

20 Creating the New Order, 1965-75 284

21 The New Order since $1975 \quad 304$

$\begin{array}{lr}\text { Notes and References } & 310\end{array}$

$\begin{array}{lr}\text { Bibliography } & 326\end{array}$

$\begin{array}{ll}\text { Maps } & 351\end{array}$

$\begin{array}{ll}\text { Index } & 361\end{array}$ 


\section{List of Maps}

The Indonesian Archipelago 352

Sumatra and the Malay Peninsula 353

Java and Madura $\quad 354$

Bali and Lombok $\quad 356$

$\begin{array}{ll}\text { Kalimantan } & 357\end{array}$

$\begin{array}{ll}\text { Eastern Indonesia } & 358\end{array}$

$\begin{array}{ll}\text { Archipelago Topography } & 359\end{array}$

World War II in the Pacific, with dates of major Allied battle victories, 1942-5 360 


\section{Preface to the First Edition, 1981}

This is a textbook designed for the serious student who wishes to investigate the history of Indonesia since the coming of Islam. It is intended to meet a need found by those whose study has been hampered by the large number and specialised nature of the major works on the subject, the high proportion of these which are written in foreign languages and the difficulty of gaining access to some of them. Students have also found that the existing literature sometimes over-emphasises either colonial aspects or the exoticism of Indonesia, and fails to provide a clear chronology within which to orient their study. This book therefore aims to provide a basic but detailed narrative of Indonesian history since $c$. 1300, an introduction to the major issues of the period and a guide to the most important published secondary sources (or primary sources where no adequate secondary sources exist). My aim is, thus, to facilitate students' progress to more advanced levels of study. The need for such a book has been evident for some time, but it is only recently that the study of Indonesian history has reached a sufficient level of coverage and sophistication over the whole period for such a textbook to be possible. Significant gaps remain in our knowledge, but the major lacunae have now been investigated.

Indonesia's recorded history does not begin where this book begins, but about a thousand years before. The earliest inscriptions of the Indonesian archipelago are on seven stone pillars from Kutai in East Kalimantan, which on palaeographic grounds are dated to $c$. $\mathrm{AD} 400$. Chinese references are also available from a very early time. Indigenous sources and Chinese records have enabled scholars to reconstruct much of the history of the pre-Islamic states of Indonesia, which included some of the major empires of the ancient world. One of the greatest of these, Majapahit, is discussed briefly in Chapter 2 simply because it falls within the chronological limits of this book.

These pre-Islamic states were Hindu-Buddist, and they left major literary and artistic legacies which, as will be seen in Chapter 5, continued to be influential long after the coming of Islam. The social, administrative and political traditions of these states also had an abiding influence. This early period has many problems of evidence and interpretation and is in much need of further study. For this reason, I decided not to attempt to cover it in this book. Some important works on Majapahit are listed in the notes and references for Chapter 2. On the other pre-Islamic states see Krom, Hindoe-Javaansche geschiedenis; Coedès, Les états hindouisés (in English as Indianized states of Southeast Asia); Wolters, Early Indonesian commerce, and van Naerssen's essay in van Naerssen and de Iongh, Economic and administrative history of early Indonesia.

The period since $c .1300$ appears to me to make a coherent historical unit, 
which this book calls Modern Indonesian History. There are of course significant sub-periods within modern Indonesian history, as is reflected by the division of the book into parts and chapters. Three fundamental elements give the period historical unity. The first is cultural and religious: the Islamisation of Indonesia which began $c .1300$ and continues today. The second is topical: the interplay between Indonesians and Westerners which began c. 1500 and still continues. The third is historiographical: primary sources throughout this period are written almost exclusively in the modern forms of Indonesian languages (Javanese, Malay, etc. rather than Old Javanese or Old Malay) and in European languages. Between $c .1300$ and $c .1500$ these elements emerged, and have remained ever since.

The writer of any history textbook must decide whether to give preference to broad interpretative themes or to the detailed, and sometimes confusing, progress of events. My experience suggests that students find interpretative treatments more readable but less useful than detailed narratives. I also prefer a detailed narrative in principle, for if the basic evidence is presented, readers are more able to arrive at their own generalisations or to question others'. I therefore decided that this book should give first place to the detailed historical evidence. There is no attempt here to impose any new synthesis upon Indonesian history, although of course my views are implicit throughout the volume.

This book gives the history of Java greater precedence than it may seem to deserve. There are four reasons for this. First, Java has received more historical study than the other islands and is therefore better known. Second, its people represent over half the population of Indonesia. Third, it has been the centre of much of the political history of both colonial and independent periods and exerted an influence over other areas greater than their influence outside their own regions, and thus carries greater significance for the history of Indonesia as a whole. And fourth, it is the area upon which all of my own research has concentrated and this personal element has naturally coloured the book. Further research will undoubtedly make it possible to study outer island areas more adequately in the future than is now the case.

No scholar masters more than a small portion of the primary sources for the topics covered in this book, nearly seven centuries of history over the world's largest archipelago. Much of this volume is thus a paraphrase or summary of the work of others, whose publications are listed in the Bibliography. Like any textbook, this one may at times simply repeat, and even add to, the mistakes of others. To minimise this problem I have called upon several colleagues and friends for comments upon draft chapters. Very substantial parts of the book have been read by Prof. C. D. Cowan, Prof. C. Fasseur, Dr H. J. de Graaf and Dr A. J. S. Reid. Dr J. S. Bastin, Dr P. B. R. Carey, Prof. James J. Fox, Dr E. U. Kratz, Prof. J. D. Legge, Dr Ruth T. McVey, Dr P. Voorhoeve and Prof. P. J. Zoetmulder, S. J., have also given me valuable suggestions on sections of this book. To all of them I am deeply indebted. The errors which remain are, of course, entirely my responsibility. I owe special gratitude to my students who read most of the book in draft, helped me to decide what was needed and encouraged me to believe that the book was worth writing. Many Indonesians gave me information which was invaluable for the last chapters of the book, but mostly on the understanding that it was not attributable to them. 


\section{Preface to the Second Edition}

In the decade after the first edition of this text book appeared, the study of Indonesian history advanced substantially. It was clearly necessary, therefore, to prepare a new edition if this work were to remain useful to students.

Research has gone forward in all fields with impressive results. Economic history generally, the history of the outer islands (notably Bali), nineteenthcentury Java, nineteenth-century Sumatra, the history of the twentieth century generally and particularly of the Revolution and years since 1965, have all been served by substantial new publications. Major works of synthesis and interpretation have also appeared, notably Lombard's Carrefour javanais, a work so broad in its scope that it could not be cited in any particular chapter below. These publications have both opened up new topics and shed new light on previously studied subjects.

In revising this book, I have added new passages and corrected errors which came to light in the first edition. I am grateful to colleagues and students who brought such errors to my attention and thereby made it possible for this version to be better. Additions and alterations have been made throughout the text. More substantial sections have been added on nineteenth-century Java and the 1930s Depression. Two new chapters on the period since 1965 have been written. The changes to the bibliography are, not surprisingly, extensive.

I am grateful to those colleagues who have read and commented on drafts of this revised edition: Prof. Anne Booth, Dr. Ian Brown, Prof. C. Fasseur, Prof. R. William Liddle, Prof. A. J. S. Reid, Dr. Henk Shulte Nordholt, Dr. Helius Sjamsuddin and Dr. Adrian Vickers. None of them, of course, bears any responsibility for the final text of the book.

M. C. Ricklefs 


\section{A Note on Orthography}

The various Indonoesian languages which appear in this book sometimes have differing transcription systems or orthography. For all words and proper names in modern Indonesian languages, I have used a standardised spelling based upon the reformed Indonesian system of 1972. Old Javanese appears in the standard Sanskrit transcription. For words which exist in both Indonesian and regional languages, I have ignored regional spellings (thus, Indonesian dalang rather than Javanese dhalang). For the twentieth century, however, there are exceptions which are explained below. Since the 1972 system does not distinguish among the different pronunciations of the letter $e$, I have added ě to represent /ə/ (like the $e$ in 'fallen'). The character $e$ is pronounced either $/ e /$ or $/ \varepsilon /$ (like either the $a$ in 'fate' or the $e$ in 'set'). In some names which are commonly used in English, I have used a conventional spelling (thus, Malacca rather than Mĕlaka and Java rather than Jawa).

Consonants have generally the same value as in English except for $c$ which is pronounced like the $c h$ in 'chair' and sy which is pronounced like the $s h$ in 'share'. Vowels are also pronounced as in English, except for the $a$ in Javanese words which is pronounced rather like English $o$ when it appears in penultimate and final syllables without final consonants. Thus Mangkunĕgara is pronounced 'Mangkuněgoro' but Mangkuněgaran is pronounced as it is spelled. As an aid to pronunciation, it is generally true that the stress in Indonesian languages falls upon the penultimate syllable.

As local scripts gave way to romanisation in the twentieth century, a variety of spellings was used. In this book I have followed the principle of spelling personal names and publication titles as they were spelled at the time. Organisations, however, have been spelled according to the standard 1972 system unless there is a clearly established convention in modern scholarly works (thus, Budi Utomo rather than the correct form Budi Utama).

In the twentieth century individuals used Dutch orthography and either pre-1972 or (now) post-1972 Indonesian orthography. Javanese commonly use $o$ rather than $a$ where the latter is pronounced 'o'. The pre-1972 orthographies differ from the 1972 system primarily in using Dutch rather than English consonants: $t j$ rather $c, d j$ rather than $j$, and $j$ rather than $y$. Dutch orthography additionally differs in using $o e$ for $u$. Thus, in the twentieth century the Javanese name Sujana (pronounced 'Sujono') might be spelled Soedjana, Soedjono, Sudjono, Sudjana, Sujana or Sujono. In the last two cases, there is no way of knowing whether this is a person named Sujana using the 1972 system or one named Suyana using the pre-1972 system.

For Arabic words, names and titles, a conventional transcription system is used. Chinese names are given in Pinyin, but the first time a name is mentioned it is also given in the Wade-Giles transcription if this differs from Pinyin. Wherever I have been able to establish them, life- or reign-dates are given when an individual is first mentioned. 